\title{
Studies on the Phosphorus Retention of Different Soil Types in a Pot Experiment with Perennial Ryegrass
}

\author{
K. SÁRDI and P. CSATHÓ \\ University of Veszprém, Georgikon Faculty of Agriculture, Keszthely and \\ Research Institute for Soil Science and Agricultural Chemistry (RISSAC) of the \\ Hungarian Academy of Sciences, Budapest
}

\section{Introduction}

Differences in soil properties and among plant species may play an important role in the effectiveness of residual and freshly applied $\mathrm{P}$ fertilizers. However, only a limited number of experimental results are available on this subject.

Changes in organic and inorganic P fractions were studied in soils of longterm field experiments in Hungary (FÜLEKY, 1975; SISÁK et al., 2001; etc.)

Results of experiments carried out with perennial ryegrass established the better ability of this plant species to take up residual $\mathrm{P}$ from fertilizers as compared to other annual plant species (BARROW, 1980).

On the other hand, several experimental results were published showing that adsorption and supply characteristics of soils are also influenced by clay mineralogy (PRATT et al., 1969; GALINDO et al., 1971). It was observed that in soils with similar clay minerals, P fixation was higher with increasing clay content. It was also found that soils with high clay content may have an ability to neutralize the acid extracting solution and thus reduce the amounts of extractable P (KAMPRATH \& WATSON, 1980). For soils with predominantly kaolinitic clay minerals, better correlations were observed between labile $\mathrm{P}$ fractions and percent yield.

The relationship between soil P status (plant available P) and plant uptake is often described by linear regression. Recently, curvilinear or nonlinear models were applied and it was concluded that they can give better assessment for the correlation (SCHOENAU \& HUANG, 1991).

The objective of present study was to develop quantitative relationships between selected important soil parameters and phosphorus retention characteristics as well as the possible supplying capacities of experimental soils.

Correspondence to: Dr. Katalin SÁRDI, University of Veszprém, Georgikon Faculty of Agriculture, H-8360 Keszthely, Deák F. út 16. Hungary. E-mail: sardi@georgikon.hu 


\section{Material and Methods}

Pot experiments were carried out with soils originating from 9 sites of the National Long-term Fertilization Trials, differing in their main characteristics (such as $\mathrm{pH}$, soil texture, organic matter content etc.) and $\mathrm{P}$ status. Soil samples were taken after 20 years from the unfertilized control, $\mathrm{N}_{0} \mathrm{P}_{0} \mathrm{~K}_{0}$ and from plots annually fertilized with $200 \mathrm{~kg} \mathrm{P}_{2} \mathrm{O}_{5}$. ha ${ }^{-1}$ (at the $\mathrm{N}_{200} \mathrm{P}_{200} \mathrm{~K}_{100}$ level). Fertilization rates are given in the order of NPK $\left(\mathrm{N}=200 \mathrm{~kg} \mathrm{ha}^{-1}, \mathrm{P}=200 \mathrm{~kg} \mathrm{P}_{2} \mathrm{O}_{5} \cdot \mathrm{ha}^{-1}\right.$ and $\mathrm{K}=100 \mathrm{~kg} \mathrm{~K}_{2} \mathrm{O}$ ha $^{-1}$, respectively).

Perennial ryegrass (Lolium perenne L.) was grown for 5 months (i.e. 5 cuts) in pots containing $1 \mathrm{~kg}$ soil (CHAMINADE, 1960). Soil moisture was kept between $80-90 \%$ WHC of soils by daily watering.

Phosphorus accumulation of perennial ryegrass was studied in 7 treatment combinations, with two doses of NPK $\left(\mathrm{N}_{1}, \mathrm{~N}_{1} \mathrm{P}_{1}, \mathrm{~N}_{1} \mathrm{P}_{1} \mathrm{~K}_{1}\right.$ etc., where $\mathrm{N}_{1}=100$ $\mathrm{mg} \mathrm{N}, \mathrm{P}_{1}=200 \mathrm{mg} \mathrm{P}_{2} \mathrm{O}_{5}$, and $\mathrm{K}_{1}=200 \mathrm{mg} \mathrm{K} \mathrm{O}_{2}$ per kg soil).

Amounts of $\mathrm{P}$ removed by plants during 5 cuts were correlated with dry matter $(\mathrm{DM})$ production of plants as well as with the phosphorus extracted at pH 3.7 by ammonium lactate-acetic acid solution, AL-P mg.kg ${ }^{-1}$ soil (EGNER et al., 1960). Phosphorus nutrient balance was calculated from the results (i.e. amounts of initial AL-soluble P plus amounts added in the treatments were compared to those taken up by plants) to evaluate either the supplying or fixing characteristics of the experimental soils (SÁRDI, 2001).

In our previous experiments, $\mathrm{K}$ fixation characteristics as well as soil parameters significantly influencing $\mathrm{K}$ fixation of these soils were reported (SÁRDI \& CSITÁRI, 1998, 2000).

Experimental sites represent several agro-ecological regions of Hungary. Soil properties related to soil fertility were published by CSATHÓ et al. (2000).

The main soil characteristics in selected plots of the experimental sites are summarized in Table 1. Soil taxonomy was based on USDA classification.

Table 1

Main soil characteristics in selected plots of the experimental sites

\begin{tabular}{|c|c|c|c|c|c|c|c|}
\hline \multirow{2}{*}{ Soil type } & \multirow{2}{*}{ Label } & \multirow{2}{*}{$\mathrm{pH}$} & \multirow{2}{*}{$\begin{array}{c}\text { Humus } \\
\% \\
\end{array}$} & \multirow{2}{*}{$\begin{array}{c}\mathrm{CaCO}_{3} \\
\% \\
\end{array}$} & \multirow{2}{*}{$\begin{array}{l}\text { Total P } \\
\mathrm{mg} \mathrm{kg}^{-1}\end{array}$} & \multicolumn{2}{|c|}{ AL-P, $\mathrm{mg} \mathrm{kg}^{-1}$} \\
\hline & & & & & & $\mathrm{N}_{0} \mathrm{P}_{0} \mathrm{~K}_{0}$ & $\mathrm{~N}_{200} \mathrm{P}_{200} \mathrm{~K}_{100}$ \\
\hline Calcic Hapludoll & $\mathrm{NH}$ & 7.26 & 2.7 & 5.5 & 974 & 43 & 94 \\
\hline Calcic Hapludoll & IR & 7.40 & 2.4 & 8.0 & 1033 & 49 & 175 \\
\hline Typic Udifluvent & $\mathrm{MO}$ & 7.27 & 1.7 & 21.0 & 817 & 88 & 173 \\
\hline Typic Endoaquoll & $\mathrm{HB}$ & 6.43 & 3.5 & 0.0 & 523 & 17 & 131 \\
\hline Orthic Eutrochrept & $\mathrm{KE}$ & 5.92 & 1.7 & 0.0 & 653 & 19 & 89 \\
\hline Aquic Hapludoll & KA & 4.70 & 2.7 & 0.0 & 589 & 16 & 86 \\
\hline Typic Argiudoll & $\mathrm{KO}$ & 4.56 & 2.6 & 0.0 & 482 & 22 & 112 \\
\hline Typic Hapludalf & PU & 3.90 & 2.0 & 0.0 & 569 & 19 & 62 \\
\hline Typic Argiudoll & $\mathrm{BI}$ & 5.61 & 1.9 & 0.0 & 775 & 21 & 94 \\
\hline
\end{tabular}


The clay content, clay mineralogy as well as the total $\mathrm{K}$ content and CEC of the experimental soils are given in Table 2 .

Total $\mathrm{P}$ content $\left(\mathrm{P}, \mathrm{mg} \mathrm{kg}^{-1} \mathrm{l}\right)$ of experimental soils was determined after the digestion of concentrated $\mathrm{HNO}_{3}$ (Soil Analysis Standards, 1998) using ICPAES.

Table 2

Clay content, clay mineralogy, $\mathrm{CEC}$ and total $\mathrm{K} \%$ of the experimental soils

\begin{tabular}{|l|c|c|c|c|c|c|c|c|}
\hline \multirow{2}{*}{ Soil type } & $\begin{array}{c}\text { La- } \\
\text { bel }\end{array}$ & Clay & $\begin{array}{c}\text { Illite } \\
\text { in } \\
\text { clay }\end{array}$ & $\begin{array}{c}\text { Kaolinite } \\
\text { Chlorite }\end{array}$ & $\begin{array}{c}\text { Illite- } \\
\text { Smec- } \\
\text { tite }\end{array}$ & $\begin{array}{c}\text { Smec- } \\
\text { tites }\end{array}$ & $\begin{array}{c}\text { CEC } \\
\text { meq } \\
100 \mathrm{~g}^{-1}\end{array}$ & $\begin{array}{c}\text { Total K } \\
\text { in clay }\end{array}$ \\
\cline { 3 - 9 } & \multicolumn{7}{|c|}{$\%$} \\
\hline Calcic Hapludoll & $\mathrm{NH}$ & 23 & 47 & 0 & 5 & 16 & n.d. & n.d. \\
Calcic Hapludoll & $\mathrm{IR}$ & 18 & 50 & 4 & 10 & 8 & 53 & 1.6 \\
Typic Udifluvent & $\mathrm{MO}$ & 15 & 48 & 13 & 7 & 16 & 37 & 2.7 \\
Typic Endoaquoll & $\mathrm{HB}$ & 30 & 29 & 2 & 5 & 47 & 76 & 2.0 \\
Orthic Eutro- & $\mathrm{KE}$ & 17 & 59 & 10 & 10 & 6 & 24 & 2.1 \\
chrept & & & 56 & 5 & 11 & 7 & 45 & 3.0 \\
Aquic Hapludoll & $\mathrm{KA}$ & 37 & 56 & 10 & 37 & 56 & 2.1 \\
Typic Argiudoll & $\mathrm{KO}$ & 36 & 27 & 2 & 14 & 27 & 62 & 1.8 \\
Typic Hapludalf & $\mathrm{PU}$ & 24 & 33 & 2 & 14 & 17 & 41 & 2.5 \\
Typic Argiudoll & $\mathrm{BI}$ & 27 & 45 & 7 & 10 & 17 \\
\hline
\end{tabular}

Soil parameters involved in our study were as follows: humus content, $\mathrm{pH}$ values (ranging between 3.9 and 7.4), $\mathrm{CaCO}_{3}$ content $\left(\mathrm{CaCO}_{3} \%\right)$, clay mineralogy (see Table 1) and CEC, total K (SÁRDI \& CSITÁRI, 2000) and total P contents of soils (mg K and P per kg soil, respectively), P rates applied for 20 years, freshly applied $\mathrm{P}$ in the pot experiment.

Results of the experiments were computed by stepwise regression analyses using the STATGRAPHICS program package.

\section{Results and Discussion}

It was evident that soils had significantly different amounts of total P (ranging between 482 and $1033 \mathrm{mg} \mathrm{P}$ per $\mathrm{kg}$ soil) as well as phosphorus amounts determined in the AL-extract (Table 1). Long-term application of P fertilizers resulted in considerable differences in the $\mathrm{P}$ levels of soils. Thus, phosphorus supplying and retention characteristics of soils could be studied in our pot experiments. These parameters are influenced by both the fertilization history i.e. long-term effects of phosphorus and the $\mathrm{P}$ rates applied in our pot experiments. 
Average phosphorus retention and supplying capacity during the 5 months (expressed in $\mathrm{mg} \mathrm{P}$ per $\mathrm{kg}$ of soil) were calculated for the experimental soils. These results are summarized in Table 3.

It was evident from these calculations that with the exception of a Calcic Hapludoll (IR), the 20-year long-term fertilization had a favourable influence on the $\mathrm{P}$ retention of soils. However, changes were variable and ranged between 4.4 and $44.0 \mathrm{mg} P$ per kg soil. Furthermore, a rather close relationship could be observed between average $\mathrm{P}$ retention of soils and their $\mathrm{pH}$ values, i. e. as acidity increased phosphorus retention was stronger.

Table 3

Average calculated $\mathrm{P}$ retention or supply of experimental soils $\left(\mathrm{P} \mathrm{mg} \mathrm{kg} \mathrm{soil}{ }^{-1}\right)$ affected by 20 years of fertilization

\begin{tabular}{|l|c|c|c|c|}
\hline \multicolumn{1}{|c|}{ Soil type } & Label & $\mathrm{N}_{0} \mathrm{P}_{0} \mathrm{~K}_{0}$ & $\mathrm{~N}_{200} \mathrm{P}_{200} \mathrm{~K}_{100}$ & Changes \\
\hline Calcic Hapludoll & $\mathrm{NH}$ & -38.3 & +5.7 & +44.0 \\
Calcic Hapludoll & $\mathrm{IR}$ & -5.7 & -26.4 & -20.7 \\
Typic Udifluvent & $\mathrm{MO}$ & +21.1 & +27.7 & +6.6 \\
Typic Endoaquoll & $\mathrm{HB}$ & -21.6 & +4.8 & +26.4 \\
Orthic Eutrochrept & $\mathrm{KE}$ & -46.2 & -15.8 & +30.4 \\
Aquic Hapludoll & $\mathrm{KA}$ & -50.6 & -22.0 & +28.6 \\
Typic Argiudoll & $\mathrm{KO}$ & -45.3 & -14.8 & +30.5 \\
Typic Hapludalf & $\mathrm{PU}$ & -62.0 & -57.6 & +4.4 \\
Typic Argiudoll & $\mathrm{BI}$ & -55.0 & -34.3 & +20.7 \\
\hline
\end{tabular}

Based on the results of regression analyses, the importance of soil parameters were evaluated. Long-term effects of $\mathrm{P}$ application, freshly added $\mathrm{P}$ treatments, higher $\mathrm{pH}$ values and humus content had a favourable influence on the $\mathrm{P}$ retention of experimental soils. On the other hand, increasing P retention could be attributed to higher CEC, vermiculite content as well as with increasing rates of freshly applied phosphorus. It was observed that long-term effects of $\mathrm{P}$ applications on the $\mathrm{P}$ supplying power of soils were related also to the increasing $\mathrm{N}$ and $\mathrm{K}$ rates, providing a balanced nutrient supply in soils.

Results of stepwise regression analyses are as follows:

A. When soils and long-term fertilizer rates were combined, the following equation was obtained describing $\mathrm{P}$ retention $\left(\mathrm{P} \mathrm{mg} \mathrm{kg}^{-1}\right)$ :

$\begin{aligned} & \mathbf{P}_{\text {ret }}= \begin{array}{l}-0.347 \mathrm{P}_{\mathrm{f}}+20.8 \mathrm{pH} \\ \text { Vermic }-175.9\end{array} \quad \mathrm{R}=0.7 \text { Humus } \%-1.18 \mathrm{CEC}+0.103 \mathrm{P}_{\mathrm{lt}}-15.4 \\ & \mathrm{n}=172\end{aligned}$ where: $\quad \mathrm{P}_{\mathrm{f}}=$ freshly added $\mathrm{P}$ treatments; $\mathrm{P}_{\mathrm{lt}}=\mathrm{P}$ fertilizer rates applied in the long-term scale; $\mathrm{CEC}=$ cation exchange capacity of soils. 
B. For the $\mathrm{N}_{0} \mathrm{P}_{0} \mathrm{~K}_{0}$ (i.e. for the unfertilized control):

$$
\begin{gathered}
\mathbf{P}_{\text {ret }}=24.9 \mathrm{pH}-0.353 \mathrm{P}_{\mathrm{f}}+5.11 \mathrm{CaCO}_{3} \%+24.7 \text { Humus } \%-213.9 \\
\mathrm{R}=0.913 \quad \mathrm{n}=86
\end{gathered}
$$

Under the soil conditions of the unfertilized control plots, calcium carbonate content $\left(\mathrm{CaCO}_{3} \%\right)$ of soils had also significantly influenced the phosphorus retention of soils.

C. For the $\mathrm{N}_{200} \mathrm{P}_{200} \mathrm{~K}_{100}$ fertilization rates :

$$
\begin{gathered}
\mathbf{P}_{\text {ret }}=75.5 \text { Humus \% }-2.84 \mathrm{CEC}-29.6 \mathrm{~K}_{2} \mathrm{O}-10.0 \\
\mathrm{R}=0.762 \mathrm{n}=86
\end{gathered}
$$

Interestingly, $\mathrm{CEC}$ and $\mathrm{K}$ content of soils (expressed in $\mathrm{K}_{2} \mathrm{O}$ ) were also included in this equation on this fertilization level. It seems that these parameters may be closely related to some other factors influencing P retention in soils.

Generally, it can be emphasized that long-term P fertilization as well as freshly added $\mathrm{P}$ treatments had a significant role in the $\mathrm{P}$ retention or fixation characteristics of the experimental soils.

It was also evident from these results that humus content as well as $\mathrm{pH}$ values and vermiculite content of soils influenced the $P$ retention of soils.

For verifying the role and significance of other important factors, further studies are necessary.

\section{Conclusions}

In the present study, we intended to develop quantitative relationships between the P nutrient status of soils and bioavailability for crops. Residual and freshly applied P effects were also investigated in order to establish the role of selected soil parameters in P retention and supplying characteristics of different soil types in Hungary. Among these parameters, the role of soil clay mineralogy was also evaluated.

It was established that several soil parameters had significant influence on the $\mathrm{P}$ retention of soils. Regression coefficients $\left(\mathrm{R}^{2}\right)$ ranged between 0.619 and $0.285(\mathrm{n}=86)$.

Phosphorus fixation and supplying characteristics of soils are of practical importance for improving the effectiveness of $\mathrm{P}$ fertilization.

Our results may help the extensive understanding of phosphorus retention characteristics under various soil and agro-ecological conditions. These results are to be taken into account when elaborating the assessment of P status of soils. 


\section{Summary}

Differences in soil properties and among plant species may play an important role in the effectiveness of residual and freshly applied phosphorus fertilizers. However, a limited number of experimental results are available on this subject.

Pot experiments were carried out with soils from 9 sites of the National Long-term Fertilization Trials, varying in their main characteristics, such as $\mathrm{pH}$, soil texture, organic matter content and P status. Soil samples were taken after 20 years from the unfertilized control and from plots annually fertilized with $200 \mathrm{~kg} \mathrm{P}{ }_{2} \mathrm{O}_{5} \cdot \mathrm{ha}^{-1}$. Effects of long-term fertilization as well as that of freshly applied phosphorus were studied in the experiments. Perennial ryegrass (Lolium perenne L.) was used as test plant.

The objective of the present study was to develop quantitative relationships between selected soil parameters and the phosphorus retention characteristics of the experimental soils.

Amounts of $\mathrm{P}$ removed by plants during 5 cuts were correlated with DM production of plants as well as with the phosphorus amounts extracted at $\mathrm{pH} 3.7$ by ammonium lactate-acetic acid, AL-P mg.kg ${ }^{-1}$ soil. Phosphorus nutrient balance was calculated from the results to evaluate either $\mathrm{P}$ supply or retention characteristics of experimental soils.

Results of the experiments were computed by stepwise regression analyses using the STATGRAPHICS program package.

Soil parameters involved in the study were: humus content, $\mathrm{pH}$ values (ranging from 3.9 to 7.4 ), clay mineralogy, total $\mathrm{P}$ contents of soils, $\mathrm{P}$ rates applied for 20 years, freshly applied $\mathrm{P}$ in the pot experiment.

Based on the results of regression analyses, the importance of soil parameters was evaluated. It was established that several soil parameters significantly influenced the phosphorus retention of soils. Regression coefficients $\left(\mathrm{R}^{2}\right)$ ranged between 0.619 and $0.285(\mathrm{n}=86)$.

Long-term effects of $\mathrm{P}$ application, higher $\mathrm{pH}$ values and humus content had a favourable influence on the $\mathrm{P}$ retention of experimental soils. On the other hand, increasing phosphorus retention could be attributed to higher CEC, vermiculite content as well as to increasing rates of freshly applied phosphorus. It was found that long-term effects of $\mathrm{P}$ applications on the $\mathrm{P}$ supplying power of soils were related also to the increasing $\mathrm{N}$ and $\mathrm{K}$ rates, providing a balanced nutrient supply in soils.

Our results may help the broader understanding of phosphorus retention and fixation characteristics under various soil conditions.

Key words: $\mathrm{P}$ retention of soils, long-term effects of $\mathrm{P}$, soil types, pot experiments 
Present work was supported by the National Scientific Research Fund (OTKA) under Grant No. T 029355.

\section{References}

BARROW, N. J., 1980. Evaluation and utilization of residual phosphorus in soils. In: The Role of Phosphorus in Agriculture (Chapter 13). 333-359. American Society of Agronomy. Madison, WI.

CSATHÓ, P., DeBreCZENI, K. \& SÁRDI, K., 2000. Correlation between soil K and winter wheat $\mathrm{K}$ contents in a Network of Hungarian National Long-term Fertilization Trials. Commun. Soil Sci. Plant Anal. 31. 2081-2092.

ChAminADE, R., 1960. Experimentation en petit vases de végétation types d'essais pour tester l'efficacité des engrais humiques. Ann. Agron. 2. 121-133.

EgNeR, H., RIEHM, H. \& DOMINGO, W., 1960. Untersuchungen über die chemische Bodenanalyse als Grundlage für die Beurteilung des Nährstoff-zustandes der Böden. II. Chemische Extractionsmethoden zur Phosphor und Kaliumbestimmung. Kungl. Lantbrukshögsk. 26. 199-215.

FÜLEKY, GY., 1975. Changes of the soil phoshorus status in long-term field experiments. II. (In Hungarian) Agrokémia és Talajtan. 24. 291-302.

Galindo, G. G., Olbuin, C. \& Schalscha, E. B., 1971. Phosphate-sorption capacity of clay fractions of soils derived from volcanic ash. Geoderma. 7. 225-232.

Kamparth, E. J. \& Watson, M. E., 1980. Conventional soil and tissue tests for assessing the phosphorus status of soils. In: The Role of Phosphorus in Agriculture (Chapter 16) 433-469. American Society of Agronomy. Madison, WI.

Pratt, P. F., Peterson, F. F. \& Holzley, C. S., 1969. Quantitative mineralogy and chemical properties of a few soils from Sao Paulo, Brazil. Turrialba. 19. 491-496.

SÁRDI, K., 2001. Studies on the phosphorus adsorption and supplying capacity of soils in pot experiments. (In Hungarian) Agrokémia és Talajtan. 50. 226-246.

SÁRDI, K. \& CSITÁRI, G., 1998. Potassium fixation of different soil types and nutrient levels. Commun. Soil Sci. Plant Anal. 29. 1843-1850.

SÁRDI, K. \& CSITÁRI, G., 2000. Studies on the potassium fixation of soils at different temperatures. Commun. Soil Sci. Plant Anal. 31. 2359-2365.

Schoenau, J. \& HuAnG, W. Z., 1991. Anion-exchange membrane, water, and sodium bicarbonate extractions as soil tests for phosphorus. Commun. Soil Sci. Plant Anal. 22. 465-492.

SisÁK, I., SÁRDI, K. \& PALKOVICS, M., 2001. Water soluble P as affected by freshly applied and residual P and P fractions of soil. Commun. Soil Sci. Plant Anal. (In press).

Soil Analysis Standards (MSZ 21470-50) 1998. Environmental Soil Analysis. Determination of Total and Soluble Toxic Elements, Heavy Metals and CrIII. (In Hungarian). 